\title{
SCIENCE IN SURGERY:
}

\section{BEING}

\section{THE H U N TERIAN ORATION \\ Delivered at the Royal College of Surgeons of Ensland, Tuesday, Febricary 13 th, 1877 .}

By SIR JAMES PAGET, BART., D.C.L., LL.D., F.R.S., Consulting Surgeon to St. Bartholomew's Hospital, etc.

MAY it please your Royal Highness, Mr. President, my Lords and Gentlemen,-I have no doubt it is my first duty to offer to your Royal Highness the thanks of the whole College of Surgeons for your presence here to-day. In honouring the memory of John Hunter, you make us more than ever proud to be the guardians of his museum and his reputation; you make us more than ever anxious to promote that true scientific surgery of which we reverence him as the great founder and we shall venture to believe that your Royal Highness approves the efforts of this College for the public welfare, and is anxious to promote the sciences, in the cultivation of which our reputation and our utility are maintained. On all these grounds, and on many others that need not be told to-day, I venture, for the whole of the College of Surgeons, to render to your Royal Highness our very respectful and our grateful thanks.

When time and the favour of my colleagues in the Council brought to me the occasion of delivering the Hunterian Oration, I thought it right to study afresh the character of John Hunter; and now I beg your leave to offer some of the facts and thoughts to which, in my study, I have been led-chiefly to tell, if I can, what were the motives of John Hunter in his scientific life, and what were the chief characteristics and methods of his work; to tell also some of his achievements and the lessons that may be read in the story of his life. I may thus, I hope, however imperfectly, fulfil the design of the founders of the oration by promoting the honour of John Hunter, and perhaps even the advancement of surgery, by showing in his illustrious example the good influence of the scientific mind.

The motive which at first urged John Hunter to the pursuit of science seems to have been only the necessity of earning his livelihood : for we find him at first as the youngest child of a Scotch laird, idle and negli gent of education. In the first twenty years of his life, he showed no desire for the knowledge of science, or any of the arts that minister to it, or, indeed, for any intellectual pursuit whatever. We find no tales of early enterprise, no childish love of Nature, no signs of the future mental power. When he was $\mathbf{1 7}$, he tried to assist a brother-in-law who was a bankrupt cabinet-maker at Glasgow, and it seems probable that, if he had been successful, cabinet-making might have been the occupation of his life. But happily he failed. His brother-in-law was past helping, and then, after two years more of idleness, what was next to be tried ? His brother, William Hunter, was prosperous in London; he was beginning to be esteemed as a great teacher of anatomy and surgery ; so he offered to assist him in his dissections, and, if that should fail, he would go into the army. Thus, in mere idleness or of necessity, with no other reason than that there was nothing else to be done, John Hunter drifted into the opportunity of scientific studydrifted into the career into which he was to become great amongst the greatest men of science, and amongst all the surgeons of all times the most renowned. It seems strange that a mind so remarkable, so vigorous, so self-willed as John Hunter's proved, should not have shown or felt some consciousness of its power till it was brought to scientific study. He had not lived in darkness or among dull people. His father was a shrewd and sensible man; his mother was well educated both his brothers and at least one of his sisters were persons of remark able mental power. Among these his mind had had opportunities of culture and of exercise, but he neglected them as if they were to him useless. And he had lived amongst the same wonders of the organic world, the same truths and utilities in Nature, as moved him in his later years to restless study. But he passed them all by unheeded; no desire of knowledge was stirred in his mind till he came into the presence of scientific men at work. It may be that now, for the first time, his mind had reached the maturity necessary for the desire of scientific knowledge; but I think it is rather that now, for the first time, he found in the society of his brother both the projects and the method of work for which alone he was naturally fitted. In 1748, when John
Hunter came to London, there was great intellectual activity in all the medical sciences; and William Hunter was in the midst of it. $\mathrm{He}$ was an intimate associate of the best minds of the time, the best lecturer on and the best teacher of anatomy; fluent and well read; enthusiastic in his devotion to science and to art; a very keen observer, and a laborious collector, wishing to devote all that he could earn in practice to the increase of his museum and his means of teaching. We may, indeed, count William Hunter to have been the first great teacher of anatomy in England, the founder of the first great school ; among all the biologists of his time and country, second to none but his brother.

Now, to pass from the idleness of a Scoteh farm into the activity of life such as Hunter found here was like being born into a new world; and this was the very world, if not the only world, in which the best parts of his mind could live and grow; for he had a natural fitness for the study of living things. For other things he seems to have had no greater desire or capacity of knowledge than ordinary men have. But this natural fitness was, in the first instance, wholly intellectual. There was no love or desire in it; and so the mind had no motive power until it was set to its right work, and in work found happiness. For the happiness of intellect is in its work; that of the highest intellect in vigorous self-guided work. The highest intellects find a happiness, the desire of which is their energising motive, not in the reception nor in the mere possession of knowledge, but in the process of acquiring it and of using it in thoughtful exercise. Moreover, to some intellects, and among these some of those by whom the greatest results of science have been achieved, there is but one kind of knowledge which satisfies either in the getting or the having. To Hunter there seems to have been no great intellectual happiness except in the pursuit of the knowledge of living things; and to this he was now brought, and hence onward there was no lack of motive. The mind that had been idle, heedless and aimless, had come to its right field of action; and in that field every opportunity of intellectual pleasure and exercise was afforded to it, and it grew into capacity for all. Gradually the desire for knowledge grew to be an insatiable passion-a motive to incessant work. With this passion another coincided. Hunter had a passion for collecting. He may have learned it of his brother; or he may have only followed the fashion of the time, which was as dominant then as it is now; but I think it was natural to him--a natural instinct for gathering and keeping ; and it worked with his desire for knowledge, and each continually animated and provoked the other. It cannot be maintained that Hunter's desire of collecting was only secondary to his desire of knowledge. Science gave it its first and chief direction; and his great ambition was to have a grand museum, richly illustrated with catalogues and drawings. If he could, he would, I believe, have collected everything by which he mişht show to himself and his friends every fact in biology that he could find. But even this would not have satisfied his love of collecting. He collected a crowd of things besides, that must have been useless even to himself and must have helped to keep him poor : pictures of considerable cost; engravings; works of art in ivory, bronze, and marble; stuffed birds; and implements of savage warfare. With all these, his house in Earl's Court must have looked like a curiosity shop. This may easily be pardoned. No earnest collector ever yet bound himself within the limits of science, utility, or prudence; and if an extravagant love of collecting, silly as it often is, need be apologised for, the example of John Hunter may be quoted, for it Jed him constantly into wider and deeper ranges of study, and it incited him to the industry and skill with which he collected the great stores of facts that are treasured in this College. Grathered around them now are the museums of the College itself, twice as large as his own; and they form what Hunter longed to see-the greatest and best museum of anatomy in the world. One other motive of Hunter's scientific life should be mentioned. $\mathrm{He}$ was a master in all the arts of anatomy-dissecting, injecting, and all the then known ways of displaying specimens. I suspect that his first success in life was that which is told of his first dissection. It is said that he was so fond of this study, that it was among the motives that induced him to go beyond the study of human anatomy into that of comparative anatomy, which before his time had hardly been pursued in this country.

These were the motives of John Hunter's scientific life; and they deserve study, for he led that life with as much purity and simplicity as any man. Doubtless, as we read his biography, we may trace the influence of other motives, which added to these their various forces ; but they were all casual and subordinate, altogether outweighed by the constantly increasing power of those which I have mentioned, and chiefly by the desire of knowledge; and that desire continued to increase with him with indulgence, with contest against difficulties, with 
the constant presence of new objects for his study, and with the encouragement of success. He filled himself with knowledge, and through knowledge he became an ardent lover of Nature. I say "through knowledge"; for Nature, in her manifold perfections, inspires many linds of love, and Hunter's was almost wholly intellectual. Ile had none of that love which moves the poet, or the idealist, or the thenlogian; for, in truth, neither poetry, nor idealism, nor theology ever coloured the simplicity of his scientific mind. He had the social love of Nature, and he writes and spealis of the animals around him as if they were his compan:ons. But his chief love was for the charms of trath that lie hidlen teneath the veiis, appearances of Nature; and his love for the e vias continually increased when every search revealed the utility of anl he saw, the perfection of acljustment of everything to its furpose, the evillence of design in every change, the evidence of $a$ grandeur in a worlel of infinite variety of form, held stedfast by few law's. All these were motives to fresh study; and I cannot doubt that he attained to that great achicrement and satisfaction of the intellect when it can rest in a loving contemplation of the truth, loving it not only because it is right, but because it is beautiful. I cannot doubt that there is giren to some high intellects, in view of a great field of scientific truth, a source of as pure delight as are the sensuous beaties of Nature to a cultivated artist's mind, or virtue to the enlightened conscience. I Imiter had a pure cal m hirppiness in such contemplations. So Reynolds, his fiiend, seems to tell of him ; for in that masterpiece of portraiture which tcaches like a chapter of biugraphy, Hunter is not shown as the busy anatomist or experimienter scarching for objective facts; the records of his worlis are in the background, and he is at rest, looking out, but as one who is looking far beyond and away from things visible, into a world of truth and law which can only be intelleciually discerned. In the clear vision of that world was his reward. It may be the reward of all who will lead the scientific life with the same devotion and sincerity.

l.st me now spcak of some of the characteristics of his work and of his method. That which first and always strikes one is the rast quantity of work that he did. It is recorded of him by one of his pupils that " he rose regularly at the dawn of day, and never ceased from his labours until the night was far adrancel"; by others, that he allowed himsel only five hours for sleep; and by another, that, when he gave him a letter of introduction, he was asked to call on him the next morning a five o'clock, and at that hour he found him already at work in his museum. Such as these were the habits of $\mathbf{H u n t e r}$ for at least the last thirty years of his life. And, reckoned in mere quantity, few men have left so large results of scicntific labour as Hunter did. Besides the four published volumes of his works, he left many in manuscript, all written or dictated by himself. There is evidence that he dissected the bodies of five bundred species of animals, and, of some of these, several examples. He left records of three hundred of these dissections ; and these included none of his studies of human anatomy, or of the hundreds, or even thousands, of morbid structures which he examincd. His museum contained nearly fourteen thousand specimens; and all these were either prepared or, at least, very closely studied by himself; and this was all the work of about thirty years, during the whole of which time he was in the active practice of surgery. Even his "amusements", as he cails them, were such as idle men would cill hard work. "I amuse myself", he says, "with bees"; and the risult of his amusement is in essays, which the best recent writer on the subject calls almost faultless. They might have served alone to gain for him considerable scicntific reputation. In evidence of the quantity of work which he would devote to a single subject, let me read to you what he states of his observations on the development of young birds in eggs. After many trials, which were to him unsatisfactory, to investigate the subject in the eggs of chickens, he says: "I kept a flock of geese for more than fifteen years; and, by depriving them of their first brood in my investigation, they commonly bred again the same ycar. Ard as hours make a difference in the first days, it becomes necessary to cxamine in the night as well as in the day, by which reason the latter brood in the summer is best adapted, having then short nights." Surely, one might suppose that this was the one great work of his life, this hourly examination by day and night over parts of fifteen years. Yet it seems, in truth, to have been only a casual by the way pursuit. lie lecame, indeed, so enchanted with the study of young birds in eggs, that he says "one would almost fancy that this mode of propagation was intended for investigation". But though thus he reached very far beyond the results obtained by any before him or in his own time, he did not publish the results, and they were not known until many ycars after his death. The range of Hunter's work matched with the time which he devoted to it. Never before or since-I think I am safe in saying this-was anyone a thorough investigator and student in so wide a range of science. Hie was an enthusiastic naturalist; as a compara- tive anatomist and physiologist, he was unequalled in his time; among the few pathologists, he was the best ; among the still fewer geologists and students of vegetable physiology, he was one, if not the chief; and he was a great practical surgeon. He was surgeon to a large hospital in London, and for many years held the largest practice in the metropolis. In all these things at one time, no one but Hunter ever was eminent and successful ; for it is not only in the range of his study, but in the thoroughness and depth of it that he is distinguished. It is not possible, indeed, to point out by example the thoroughness of Hunter's studies. Let it suffice to say that, in the whole range of subjects which I have just now indicated, he studied as thoroughly as was pos. sible. There is not one of them in which he did not make investigations wholly original; not one of them of which he did not enlarge the area very far beyond that which had been covered hy his predecessors; not one of them in which he did not leave facts and principles on record which it is impossible to count and very hard to estimate.

In all these characters of Hunter's works, we see that which was the dominant character of his mind; massiveness and grandeur of design were indicated in all to which he applied himself. And in perfect harmony with this, was the simplicity of his ordinary method of work. It con. sisted mainly in the orderly accumulation of facts from every source, of every kind, and building them up in the simplest inductions. If he had been an architect, he would have built huge pyramids, and every stone would have borne its own inscription. He knew nothing of logic, or the science of thought. He used his mental power as with a natural in. tellect. He worked with all his might, but without art. I know no instance so striking as is in him, of the living force which there is in facts when they are stored in a thoughtful mind.

But Hunter was not only a great observer, he was a very accurate one. I think it would be difficult to find in all the masses of facts which he has recorded, any one which was either observed or recorded erronenusly. If there are errors in his works, they are the errors of reason, not of obscrvation. And it may be noted, as a singular example of his accuracy, that when he tells his inferences, it is generally with expressions implying that he regarded them as only probable. A fact he tells without conditions; when he generalises, it is with "I suspect", "I believe," "I am disposed to think", or the like, and I believe there cannot be found one instance in which he endeavoured to add to the force of evidence by any strong assertion of his own opinion, as if his opinion should be taken for weight in a balance of testimony. Nay, there are very few instances in which, on any of the larger questions of biology, Hunter spcaks with any positiveness at all. No one seems to have known better than he did that in science strong convictions are not usually the signs of knowledge. He seems to have thought he had never reached further than the nearest approach to truth which was at that time attainable, and that a year or more of investigation would bring him nearer to the truth, and then that which now seemed right would be surpassed or set aside. He used to say to his pupils in his lectures, "Do not take notes of this; I dare say I shall change it all next year".

Another instance of this singular caution was in the slowness with which he published. He was at work for eighteen years before he published anything in his own name. He was forty-three when he published his first work, that on the Teeth, and for his great work on the Blood and Inflammation he may be said to have begun collecting materials while he was a student. Several of the experiments recorded in it for the first time were made while he was house-surgeon at St. George's Hospital. He worked at it for forty years, and he had only just begun to print it when he died.

And his patience was equal to his caution. Abernethy, who knew him well, says, "It is scarcely credible with what pains Mr. Hunter examined the lower kinds of animals", and he quotes Mr. Clift as saying that "he would stand for hours motionless as a statue, except that with a pair of forceps in either hand he was picking asunder the connecting fibres of some structure" that he was examining. A very striking picture this, for this was in the last year of IIunter's life. He was growing old, and he had lately been very ill, and he knew that he was in constant peril of the sudden death in which at last he fell ; yet he would stand for hours motionless as a statue; patient and watchful as a prophet, sure that the truth would come; it might be in the unveiling of some new structure, or in the clearing of some mental cloud; or it might be as in a flash in which, as with inspiration, intellectual darkness becomes light.

Now in these things we may discern that, in the character of Hunter, the massiveness and grandeur of design of which $I$ have spoken, and which were matched with a strong will, and a power nearly equal to them, were combined with a singular scientific prudence; and yet he was very fond of scientific enterprise and speculation. The characters may seem incongruous; but they are met with in the 
most attractive minds, and they may be studied in Darwin and in some others, the best of our own times. His enterprise was shown in his devotion to experiment. If there were one kind of truths which he preferred before all others, they were those which he could thus obtain. He seems to have had a keen delight in that condition of the scientific mind in which it stands waiting for the solution of a problem which itself has made-standing always, as it were, in the presence of the about-to-be-known. And, as he was always projecting his mind beyond his knowledge, thinking out beyond the course of facts which he could discern in the normal course of nature, so he made every question that he could to be the subject of ingenious experiment. He used to say to those about him who seemed too fond of thinking about matters that might be known, "Do not think; try ; be patient ; be accurate" ; and yet, when he came beyond the reach of observation or experiment, there were few who were so bold in thinking as Hunter was ; and I believe that his long experience in the art of experiment justified him in this, by training and educating his mind for yet further enterprises. For a well-devised experiment, such as many of Hunter's were, deserves the name of project; in that the mind, throwing itself forward in advance of facts already ascertained, discerns that the truth must be in one of two or a few more probabilities, and then devises means for deciding where it is ; and a mind which has been long trained and practised in this art, acquires sometimes the power of thinking out very far beyond the range of facts, and of discerning far off, and even sometimes from a standpoint of partial error, some great truth. Hunter seems to have possessed the power, in a very remarkable degree, of sometimes thus thinking the truth. For example; he thus thought the truth that the blood is alive, and that not in any supernatural or transcendent sense, as others before him had thought, but in the same sense as are all other parts of the same living body. This was a true discovery, of which he saw all the bearings, and it led him to the first steps in a true pathology of the blood. Yet, if we look at the facts on which he based it, we must believe now that they were very insufficient, and we must assign the discovery mainly to the force of a strong clear mind, looking out far beyond its facts.

So in another instance ; in the observation which $I$ have just quoted on the development of the bird within the egg, he discerned that marvellous law in development, that every higher creature in its passage from its embryo to its perfect state passes through a series of changes, in each of which it imitates the form of some order lower than itself. And this was no mere lucky guess just made and then left. Hunter saw the fact in all its force, and it became to him a fruitful doctrine.

And $I$ find at least one instance of his projecting his mind far into a doctrine of evolution. When writing on hermaphroditism, which he studied very carefully, he says in a footnote, "Query; Is there ever, in the genera of animals that are natural hermaphrodites, a separation of the two parts forming distinct sexes? If so, that may account for the distinction of sexes ever having happened."

It is not strange that one who could thus sometimes think out rightly far beyond the truth, should strive for a decision on that great question in physiology which, from the earliest days of scientific inquiry, has never ceased to be discussed-the question, What is life ? Hunter strove for a decision on it, and his opinion had great influence upon his own pursuits, and much more, for a time, on his reputation and his influence in science. He spoke of life as a vital principle, as something separate from organisation; and, although he spoke also of a materia vite diffusa and a materia vita conservata in the brain, yet he did not regard it as material, or any property of matter. I believe that he meant by vital principle that which Joseph Henry Green, the most eloquent and philosophical of his interpreters, held : " a power anterior in the order of thought to the organisation which it animates, maintains, and repairs ; a power regenerative and constructive." But Hunter could not clearly express this, and I believe he could not clearly think it; for he wrote upon this and several allied subjects very obscurely-so obscurely, that we cannot but believe that his own mind was in uncertainty. And this, I think, we must assign to one of the few intellectual defects we can discern in him, namely, a singular inequality in the powers of language and of thought. In every mind, thoughts and words are so closely interwoven, that each shares always the qualities of the other. Thoughts and words are like mutual reflectors; if either of them distort an object placed between them, the other cannot but receive the distorted image and reflect it. Or, each is alternately master and servant. Thoughts use words for their expression, and then the words take part in directing the next thoughts; if either be erroneous or defective, the other suffers with it. Now, Hunter was a great master of facts; and in plain and customary English he could, with great power, collect, compare, arrange, and construct whatever might be made of them; but he was not a master of words. His strong large mind does not show in any instance that subtlety which, whether in thinking or in writing, can use accurately many words of scarcely different meanings-a power which is essential to the discussion of abstract ideas, and the want of which not only hinders the expression of thought, but hinders even the process of thinking.

This defect in Hunter was, I believe, a natural one. Most of the defects that might be assigned to imperfect education he corrected in his later years; but to the last he was, whether in thinking or in writing, in language most incomplete; and his mind, strong as it may have been by nature for thinking, was hindered and baffled by its weak associate. Nevertheless, however incomplete his idea of the vital principle may have been, he used it very widely as an hypothesis. It guided him continually to large ranges of study: it enabled him to throw off the shackles and the erroneous chemical and physical doctrines of life which had prevailed in his time; and it served as a single band to hold together all the subjects of his study. Moreover, some of his pupils made it the groundwork of his reputation; and, although it was neither a new doctrine, nor one essential to his system, yet it became the chief dogma of his school, and it served at least the useful purpose that, in a time of need, it kept alive the influence and reputation of his great name.

But what I think most to be observed in respect to the character of Hunter on this point, is the very careful estimate he made of the relative values of hypotheses and facts. He bore well that severest test of the scientific mind, the test of its power to resist subjection to its own hypotheses. Feeble men worship the works of their own minds; they fall down before their own idols made of words; they have more confidence in what they call their principles than they have in plain facts. It was not so with Hunter. He may have admired the hypothesis of a vital principle, and he used it very wisely, but he admired much more the accumulation of facts and the plainest inductions from them. $\mathrm{He}$ gathered them as with avarice, he stored them up in memory and in manuscript, and he read in them as he best could the laws of life. This was the principal, the best, and abiding part of his work; and hence comes his great influence in science. But in the mind of Hunter, thus careful in observing and able in thinking, we have an epitome of the whole course and temper of biology. It is eminently a science of observation; yet none who love to think can study the phenomena of life without asking themselves, What is life? or even beyond this, Whence is it derived? An imperious instinct commands us to look beyond or beneath the phenomena. We cannot believe it to be im. possible that we should reach far beyond the evidence of the senses; and when beyond phenomena we discern, as we believe, the operation of forces measurable and correlated, still we cannot stay here; for the knowledge how forces act tells us nothing of their origin; and this, especially in respect of life and mind, is what we most earnestly desire to know-What is life, and whence is it derived? Is it a power anterior to the organisation? Is it a power originative and constructive?

Now, I cannot doubt that in the doctrine of the correlation of physical and vital forces we are nearer to the truth than we were in the Hunterian doctrine, which held that life is something altogether alien and different from other forms or methods of activity; but holding the correlation and mutual conversion of the forces does not determine the precedence of either the one or the other. If the vital and physical forces are mutually convertible, either may have preceded the other ; the vital force may have preceded the physical, although life appeared late upon this planet, in any of the phenomena in which we can now study it ; and even if we were to hold the possible conversion of physical or vital into mental force, into consciousness and will (though against this what I believe to be my consciousness and will are utterly repug. nant), yet this would not prove the precedence of the physical force. The opposite conversion can be as well or as ill traced. Mental forces may have preceded physical ; mind may have existed before any of the properties of matter ; and thus, even in the view of science, the first essence may have been a Being willing and knowing, and the prime source of all the forces whose operations we now trace. I believe there is not anything in science to disprove such a belief as this; but I doubt whether it be in the power of science yet to determine an order of precedence amongst the forces. I cannot imagine anything before a natural force except a supernatural will; and a belief of this kind is held by untutored minds as if it were instinctive knowledge. For man seems naturally prone to believe that, beyond all that there is in the world, there must be a mind, or minds, in the likeness in which his own is created, and with which he is in some kind of personal relation. But science cannot yet reach to the proof of these things; and, until it can reach to proof, science cannot rest and must not rest; but the firm and self-guiding belief that a supernatural Will and Knowledge was, and is, and will be, rests on the whole and manifold evidences of 
the Christian faith. These may seem often opposed to what we believe to be true in science. Then let us wait. Time-or, if not time, eternity-will prove that science and the Christian theology are but two sides of truth, and that both sides are as yet only known in part.

I pass from this, which may seem a too far digression, that I may speak of one character of Hunter's mind, which seems to have remained unchanged even from the days of his idleness on the Scotch farm. I mean the unconsciousness of his own mental power. He could be provoked, in his later life, into saying that he knew better than some of those that spoke ill of him; but he said he felt a mere pigmy in the presence of the work he had to do; and even the se:asitiveness and vexation with which he sometimes speaks of rivals is enough to prove that he doubted whether he did work good and great enough for permanent renown. He stands, as he stands all other tests, so this of mental greatness, well-the test of self-unconsciousness; and it is happy for science be did so ; for, if Hunter had thought of himself as we think of him - wherein, we must admit, he would only have thought justly-he must have lost his time, being self-enamoured, in seeking work that would be adequate to the grandeur of his mind, or putting his mind in attitudes that might command just homage. And, according to his own judgment, he would have failed; for, as he wrote with more than usual disparity of words and wisdom, "There never was a man that wanted to be a great man ever was a great man".

And now, what were some of his achievements? What was his influence in science? We have seen that his work was various; so were its consequences. Hunter worked at life in both health and disease; and in his mind they were manifestations of the same power and design, although sometimes in diseases overborne; but he held them to be parts of one science to be studied alike. Yet he had too much common sense not to see the broad practical differences between health and disease, and he studied them separately and he taught them separately; and, in estimating his influence on science, we must make a similar separation. His greatest work was on Physiology. Holding, under that name, the science of the whole normal life of all things that live and have lived, he grasped it with the widest mental grasp. He saw and he taught the way to the whole science of life; and this he did as of his own force. He neither followed other men, nor merely drew a plan on which other men would work; but, with his own mind he planned, and with his own hand he wrought, a larger and truer work in the whole science of life than any man before him. And in this work no man succeeded him. His lesser work, great as it wasgreater, I believe, than that of any man before or since-was in Pathology ; and the influence of this lesser work was greater than that of the greatest of the achievements in physiology; for from among his pupils there went out all the great surgeons of the time next after him-Abernethy, Astley Cooper, Cline, Home, and Blizard. These all boasted of being his pupils; they all taught after his method, and they made the method a tradition in the schools. Hunter was thus, in the fullest sense, the founder of a school of surgery. But from amongst his pupils there went out not one who devoted himself to physiology-not one who worked at it as he did. Although he was an active and influential member of the Royal Society, intimate with all the leading men of science of his time, tile founder of a scientific society of his own, yet, in his study of comparative anatomy and physiology, not one of the younger men of science followed him. In ali these deeper studies of life, Hunter had not one disciple.

Now, how may we explain so marked a contrast as this? I believe by the different levels of men's minds at that time in the two subjects. There was not, at the time, in this country either capacity or desire for any of the deeper studies of life. There was, as we say, no taste for them; for no one but Hunter had at that time tasted intellectual happiness in the study of them. It was not so in pathology. The practitioners of medicine and surgery were willing and able to receive his teaching; and although, during his life time, it never excited enthusiasm, yet the best of those who heard it could not but see that it was the right way to truth. In comparative anatomy and physiology, Hunter was in advance of his time : not far in advance, for Cuvier and Meckel quickly followed; and then these sciences became, as they have remained ever since, pursuits of the largest intellects. It may well be that, if Hunter had been more apt to teach, he might have made more disciples. Some men, by mere personal influence, can make disciples. Hunter had none of the power by which these men make their schools. He had no attractions easily to be felt; he was too busy and occupied to exercise influence over men. His lectures are said to have been dull and tedious, and ill delivered; and there was really nothing but the power and example of his work that could move men to follow him. These were enough in medicine and in surgery ; they were not enough in the deeper sciences of life; and so it came that, when Hunter died poor and with his work half finished, there was not one who could complete his unfinished essays or write the catalogue of his different collections; there was not one who knew the extent or depth of the work he had done. His works had been like the waves in advance of the on-coming tide. A few of those that watched them, thought them beautiful and grand; but they broke on the shore in what seemed like only trouble and confusion, and the tide passed over them and hid the treasures they had borne.

It was not till Owen came, that the treasures were recovered, and, by that time, others had done the work of Hunter, and had reaped the just reward. But Owen showed - partly in his catalogues of the museum, and much more in his two volumes of Hunter's Essays and Resecrches-how great and various IIunter's work. had been; how great beyond that which was shown in the essays which he published. As Mr. Flower has written of him : "Hunter had, before the time of Cuvier and Meckel, collected materials for a work which needed but the finishing touches to have made it one of the greatest, most durable, and valuable contributions ever made by one man to the advancement of the science of Comparative Anatomy."

It may seem useless to dwell on these things, and revive the vain regret that not Hunter alone, but England, lost so great renown. But it is not useless to indicate the grandeur of his character by which our English-I mean, of course, our national-school of Surgery was founded; for it is only by imitation of the founder that the worth and merit of the school can be maintained. Hunter's chief renown in surgery is told by saying that he was the founder of scientific surgery : and so he was ; for he first studied and he first taught in the light and with the methods of a large physiology those very processes of disease and repair with which the practice of surgery is concerned. There were excellent surgeons before him and in his time-sagacious, observant, practical men-by whom surgery was being rapidly advanced in both utility and precision. Not to speak of the members of the French Academy, there were, in this country alone, three at least-Cheselden, Percival Pott, and William Sharpe. Of the first two, Hunter was for a time a pupil; and it is great praise of him as a practical surgeon to say that he was worthy to be their successor; but before the time of Hunter surgery was the surgery of experience alone. In so far as it was a science, it stood by itself. It had hardly any connection even with medical science; and with the sciences beyond medicine it had no relation whatever. Between surgery and physiology there was a broad distance. No one strong mind had ever held them both, and seen that they were parts of one science, each to be studied by the other's light, each to be the test of the other's truth. This was Hunter's great work. He brought the scientific method into the study of practical surgery ; he welded scientific knowledge with the lessons of experience. In all this, Hunter was not only a great thinker, but he was a great worker. As I have said of his work in physiology, so I may say of this, that with his own mind he planned and with his own hands he did the work, and he left behind him facts and general principles in surgery which it is literally impossible to count.

But, while I thus speak of Hunter's scientific surgery, I desire to correct an error into which, I think, most of his eulogists have fallen, when they have implied that the whole of Hunter's practice was founded upon his scientific knowledge, and that no practice can be sound which is not derived either from pathology or physiology, or at least consistent with what we believe to be truth in them. Now, as for Hunter-and herein again, I think, he may be our model-he was very cautious in making deductions. No one seems to have known better than he did the danger of reasoning from physiology into practical surgery. As he says, "the man who judges from general principles only shows ignorance. Few things are so simple as to come wholly within a general principle. We should never reason on general principles only, much less practise upon them, when we are, or can be, masters of all the facts; but, when we have nothing else but the general principle, then we must take it for our guide." It is in obedience to the wisdom of his principle that, in all his works of surgical practice, it is difficult to find out that he was a great physiologist. In his work on Venereal Disease I believe there is not one sentence that would clearly tell it; and, even in his great and chielly physiological work on the Blood and Inflammation, he very seldom draws any deductions from physiology, and even the deductions from pathology to surgical practice are very few. We can see in every one of his works the same scientific mind, the same earnest desire for the collection and accumulation of facts, the same plain reading out of them, the same swiftness and accuracy in generalising; but the great effort of all is to be "master of all the facts", and then from them to draw the plainest conclusions.

A striking instance of this is in Hunter's great achievement in surgery, the invention of the operation for the cure of aneurism by tying the artery far above the seat of disease. This was no laborious 
result of physiological induction; it was a plain result of facts collected in the wards and in the dead-house. I shall not discuss Hunter's claim to the discovery of this operation, it is as clear as the discovery of any fact of science. But, if there must be arbitration between Anel and Desault on the one side, and Hunter on the other, or between France and England (for it has been almost made a national question), let an Italian (Assalini) be the arbitrator; for he had the singularly good fortune to see three decisive operations. In I78I, he saw Spezzani at Padua tie the femoral artery previously to an amputation of the thigh for popliteal aneurism; in June 1785 , he saw Desault in Paris tie the popliteal artery for popliteal aneurism, which he did not, according to the then prevalent practice, lay open; and, in December 1785 , he saw Hunter at St. George's Hospital tie the femoral artery in the sheath of the triceps muscle for the cure of the same disease - and this operation, he says, "excited the greatest wonder and awakened the attention of all the surgeons of Europe". It was indeed a splendid achievement, and its utility is not half told by counting the thousands of lives which it has heen the means of saving; for its yet greater utility is that it still abides as a great testimony of the value of the scientific mind in the practice of surgery.

Such was Hunter's great work in surgery, and this it is which still abides; for, since the time of Hunter, science has never yet been absent in the teaching of our schools. Since his time, the teaching of practical surgery has never been divorced from the study of biology. They have been cultivated in various degrees in various schools by different men, but both have held their ground, and both will still increase and grow. Yes ; both will increase, though the great master of art, the greatest practical surgeon of our time, is gone. Men will no longer watch those eyes that were so keen, nor try to imitate those hands that were so strong and yet so sensitive, so swift and light; nor wonder at that keen and clear perception, the prompt invention, the perfect calmness in the greatest difficulties. All these are gone, and with them are gone those things that endeared him to us still more-the warm heart, the friendliness, the generous rivalry, and the social grace. These are gone ; but Fergusson's lessons will still remain amongst us ; and among them will be this, that every man, according to his ability, should have both art and science, should work with both as with both hands, as if with one mind and one design. It was thus that Hunter wrought in surgery.

These are some of the works that Hunter did for surgery; and now mark what he did for surgeons. Before his time, they held inferior rank in the profession. There were some among them, men of great personal ability, who gained high rank, as Wiseman, Cheselden, Hawkins, and Percival Pott ; but for the most part they were subordinate to the physicians, and very justly so, for the physicians were not only better learned in their own proper calling, but were men of much higher culture-educated gentlemen and the associates of gentlemen. From Hunter's time, a marked change may be seen. Physicians worthily retained their rank, as they do now, and surgeons rose to it; and surgery, in the lessons of Hunter, repaid medicine for the teachings of a century. After his time, surgeons came to be the chief anatomists, and took a fair share in the teaching of all the schools; and they gained entrance into the ranks of the most cultivated class. Yes, more than any other man, Hunter helped to make us gentlemen; and the lesson of this fact is very striking, for it was not by any personal qualities, it was not by wealth or social skill, that he did this. There are but few records left of what manner of man he was ; but they tell that he was a rough and simple-mannered man, abrupt and plain of speech ; warm-hearted, and sometimes rashly generous ; emotional and very impetuous, quickly moved to tears of sympathy, as quickly ablaze with anger and fierce words; never appearing to those about him as if he were a man of large mental power ; never personally attractive ; too busy to attempt to influence those about him ; and so he had but few friends, and he obtained the personal regard of very few, and no man paid him the homage of mimicry. The whole of the influence which he exercised on surgery and surgeons was the influence of the scientific mind. What follows? Surely that, if we are to maintain the rank of gentlemen, if we are to hold this highest prize of our profession, it must be by the highest scientific culture to which we can attain ; and to this we are bound, not for our own advancement alone, but by the plainest and strongest motives of our duty.

These are some of the grounds on which, beyond all question, Hunter's memory deserves the honour that we pay to it to-day. There are many more than these ; but, in want of time, I have omitted some, and, in want of just appreciation of him, I have omitted more. Whatever one might tell of his honour to-day, his claim to honour is not yet closed for the influence of men like Hunter extends far beyond the time and space of their own conscious activity. Their true thoughts live after them ; they not only endure and remain, but, in the continuity of mental life, they really live ; they pass on from one generation to another, and in each succeeding generation they grow and are developed, and come nearer to perfection. Thus the true thoughts of Hunter still live in us, and, when we do honour to his memory, we do it not as to that which is past, but to a power still ahiding with us and doing good. His true thoughts still live in us, and they will live beyond us, never ceasing to urge and help men onwards in the pursuit of truth; for in the world of mind, he that is mortal may produce that which may have immortality.

\section{ON THE RESULTS OF RECENT RESEARCHES IN THE TREATMENT OF PHTHISIS*}

By I. BURNEY YEO, M.D., F.R.C.P.,

Physician to King's College. Hospital, and Assistant-Physician to the Brompton Hospital for Diseases of the Chest.

[Concluded from th. i6o of last numlier.]

b. Next, let me call your attention to the use of antiseptic agents in the treatment of phthisis, and especially to the use of antiseptic inla. lations.

In the first place, let us inquire if the results of modern pathological investigations give us any sound reason for the belief that antiseptic vapours can exercise a remedial influence in tubercular consumption.

Let me quote Rindfleisch's observations on "How Scrofulous Persons become Tuberculous" (Ziemssen, Cyclopadia of Medicine, vol. v, p. 639). "When we consider that scrofulous persons are especially predisposed to tuberculosis; that tuberculosis hardly ever occurs except in scrofulous persons; that tuberculous phthisis is only a combination of scrofulous inflammation and tubercle ; and that in scrofulous persons an inflammation brings with it the risk of tuberculosis, we can hardly fail to see that, in certain men, as in certain animals, inflammation runs a peculiar course. The cheesy infiltrations and suppurations of mucous membranes elaborate a poison which, when absorbed, produces tubercles. This constitutes the real relationship between scrofula and tuberculosis. The tubercular poison in most cases is thus manufactured by the patient himself.

"Pulmonary phthisis is almost always a general disease. There is first scrofula, and then a cachexia, from the absorption of scrofulous products."

Rindfleisch considers he has demonstrated that, in the early stage of pulmoncry phthisis, there is a combination of two conditions, a circumscrithed catarrh of the small bronchi at the apex, and an eruption of miliary tubercles in the acini belonging to these bronchi. "I have never seen", he says, "a circumscribed catarrh of the small bronchi without an initial tubercle granulum, nor an initial tubercle granulum without some bronchial catarrh. I believe, indeed, that the catarrh is the earlier, the tubercle the later, process". "I believe that, in the catarrhal secretions of a scrofulous person is contained the tubercular poison which becomes inoculated in the edges and corners of the narrowest portions of the bronchi", and then gives rise to the tubercle granulumı.

I quote this opinion of Rindfleisch because it seems to me to afford a pathological basis, and to give a pathological indication for certain therapeutic processes which have been again and again advocated, but which have never, at any time, thoroughly established themselves in medical practice.

If, as Rindfleisch asserts, the dissemination of tubercle through thelung depends on the infective quality of the secretion of the bronchial mucous membrane when a bronchial catarrh arises in a scrofulous person, then the very obvious remedy is to convey some vapour into the lung which may have the property of disinfecting this infective secretion. It may be objected that there is no such vapour; but such an objection is entirely without foundation, because it would require for its proof that every vaporisable substance had been repeatedly tried and had invariably failed.

There is another possible mode, indicated by modern pathology, in which antiseptic remedies might act. We might be able to add to the blood some agent capable of destroying the infective property of those substances which are absorbed from the foci of scrofulous inflammations, and which we may term the poison of tubercle. Could we administer such an agent during or immediately before the possible dissemination of such substances, we should have a remedy for tuberculous phthisis. Such, I take it, are some of the suggestions which modern pathology and research yield towards a rational treatment of phthisis.

* Read before the Medical Section at the Annual Meeting of the British Medical Association in Sheffield. 